\title{
RecQ-Mediated Genome Instability Protein 2
}

National Cancer Institute

\section{Source}

National Cancer Institute. RecQ-Mediated Genome Instability Protein 2. NCI Thesaurus. Code C96029.

RecQ-mediated genome instability protein $2(147 \mathrm{aa}, \sim 16 \mathrm{kDa})$ is encoded by the human RMI2 gene. This protein is involved in the resolution of homologous recombination during DNA replication. 